\title{
BOOK REVIEWS AND NOTICES
}

\author{
ERIK J. WIELENBERG \\ DePauw University
}

\section{Mark Murphy. God and Moral Law: On the Theistic Explanation of Morality. Oxford University Press, 2011.}

Suppose that God exists; what is the relationship between God and morality? In his sharp new book, Mark Murphy criticizes two prominent ways of answering this question (theological voluntarism and 'standard' natural law theory) and expounds a striking new answer. Along the way, he examines the nature of moral law and moral obligation. Murphy's book constitutes an excellent companion to Robert Adams's masterpiece Finite and Infinite Goods as Murphy draws on some aspects of Adams's Platonic theistic approach to ethics while at the same time subjecting Adams's view to insightful criticism. The primary audience for Murphy's book is philosophers interested in theistic ethics, but it (along with Adams's book) ought to be read by anyone interested in meta-ethics, for at least two reasons. First, it includes a number of important claims and arguments about moral laws and moral obligation that, if correct, have implications far beyond theistic ethics. Second, defenders of secular approaches to ethics can learn much by examining the best theistic approaches to ethics and considering their strengths and weaknesses.

To get a sense of the structure of the central argument of God and Moral Law, imagine a piece of cotton slowly moving closer and closer to an open flame. When the cotton is very near to the flame, it begins to burn, and eventually is entirely consumed. Suppose that God exists; what role, if any, does God play in this transaction? According to mere conservationism, God is responsible for keeping the cotton and the flame in existence, but it is the nature of the cotton and the flame that directly explain the consumption of the former by the latter. One worry about this view is that it does not do justice to God's sovereignty. On this view, God is too much in the background; as Murphy puts it, 'what happens 
between the fire and the cotton is ... entirely between the fire and the cotton' (p. 135). According to occasionalism, God is the immediate and complete cause of the burning of the cotton; the proximity of the cotton to the flame is merely the occasion for God bringing it about that the cotton burns. This view puts God right at the centre of things and appears to preserve His sovereignty. However, an opposite worry arises for this view, as it appears to imply (implausibly) that the fire does not cause the cotton to burn.

Now imagine some sadistic hooligans bullying a helpless child. This act is morally wrong; it is morally necessary that it not be performed. Again, suppose that God exists; what role, if any, does God play in explaining the moral wrongness of this act? Corresponding to mere conservationism is the view that God is responsible for keeping the act and its wrongness in existence, but it is the natural features of the act itself that morally necessitate that it not be performed. According to Murphy, this is the essence of standard natural law theory, and it suffers from the defect of failing to do justice to God's sovereignty. God is too much in the background here; He is not part of the immediate explanation for the wrongness of the act (p. 74). Corresponding to occasionalism is theological voluntarism, the view that an act that is (or is partially constituted by) a divine willing is the immediate and complete explanation for the moral wrongness of the act; the natural features of the act are morally inert. But according to Murphy, the view ' $\mathrm{t}$ ] hat natural facts have no active normative power is on its face deeply objectionable' (p. 119).

Perhaps there is a middle way. In the case of the cotton and the flame, perhaps we should say that the burning of the cotton is jointly attributable to God and the fire' (p. 146). Similarly, perhaps in the case of the hooligans and the child, we should say that the moral wrongness of the act is immediately explained both by God and certain natural features of the act itself. The centrepiece of Murphy's book is a working out of this third option, moral concurrentism (Murphy takes this to be a version of natural law theory; hence his use of the label 'standard natural law theory' for the type of natural law theory he rejects).

According to moral concurrentism, 'moral necessitation ... is immediately explained both by God and by creaturely natures', and 'this is not overdetermination, but cooperation: they somehow jointly morally necessitate' (p. 148). But how does this work? To answer that question, Murphy first draws on Adams's suggestion that the goodness of finite 
things consists in their resembling God in a particular way. Employing a delectable example that involves Murphy turning into a chicken fried steak (the delicious details of which I won't reveal here; see p. 155), Murphy argues that Adams's view on goodness should be modified so that it says that 'no created thing is simply good; it is always X-ly good (or bad), where the $\mathrm{X}$ is filled in by the kind to which the thing belongs ... whenever a being belongs to some kind, then the standards for excellence for that thing are fixed in part by its kind' (p. 159). The resulting view has it that the goodness of finitely good things consists in their 'being like God in ways that belong to the kind to be like God' - a 'theistic Aristotelianism' in contrast with Adams's theistic Platonism. So, on Adams's view, if I taste like a well-prepared chicken fried steak, then this is an excellence in me, whereas on Murphy's view it is not because tasting like a well-prepared chicken fried steak is not an excellence of human being, the kind to which I belong (p. 155).

With this account of goodness in hand, Murphy develops a theory of moral necessitation, a property that, according to Murphy, is closely related to, though perhaps not identical with, moral obligation (see pp. 166-172 for Murphy's discussion of the relationship between moral necessitation and moral obligation). Murphy proposes that moral necessitation is grounded in the goodness and badness of finite things; these goods and evils sometimes 'demand a response' (p. 162). Since the goodness of finite goods consists in their resembling God in a way suitable to their kind, we can say that 'on moral concurrentism all moral necessity is the pull of divine goodness specified by the nature of the creatures involved' (p. 162). In this way, God and creaturely natures cooperate to explain moral necessitation. To return to the case of the sadists bullying the child, the goodness of the child (and/or its life) - its resemblance to God in a way suitable to its kind - morally necessitates that the child not be bullied.

The problem with standard natural law theory is that it implies that 'God is not an immediate explainer of moral necessitation' (p. 164). Moral concurrentism avoids this problem by claiming that what necessitates is resembling God in a way suitable to one's kind. The problem with theological voluntarism is it 'excludes creaturely natures from having an immediate explanatory role in moral necessitation' (p. 164). Moral concurrentism avoids this problem by claiming that what necessitates is resembling God in a way suitable to one's kind. 
As a defender of secular approaches to ethics, I feel some kind of necessitation (perhaps moral, perhaps not) to offer some critical remarks about Murphy's worthy book. To that end, consider the distinction between intrinsic and extrinsic value, a distinction explored most famously by G.E. Moore. On the Moorean conception, the intrinsic value of a thing is the value it has 'in and of itself' or entirely in virtue of its (non-evaluative) intrinsic properties. Extrinsic value, by contrast, is the value a thing has in virtue of how it is related to other things. It seems to me that the 'in virtue of' relation here is best conceived of as explanatory in nature, so that we can say that when something is intrinsically good, it is the thing's non-evaluative intrinsic properties (or some proper subset thereof) that make it good. On this conception of intrinsic goodness, Murphy's view (as well as Adams's) implies that nothing distinct from God is intrinsically good. This is because, on Murphy's (and Adams's) view, the goodness of things distinct from God consists in their standing in a certain relationship to God; their goodness is thus extrinsic rather than intrinsic because it is explained not merely by their intrinsic properties but also by certain properties of God. This points to a possible weakness in Murphy's view. I take it that one way of testing the adequacy of a given theory of morality is to examine how well it accords with our common-sense moral beliefs. While our common-sense moral beliefs are not indefeasible, the fact that a given theory is at odds with such beliefs is a strike against that theory. Indeed, Murphy appears to take such an approach himself. As I noted above, one of his primary criticisms of theological voluntarism is that it implies that 'natural facts have no active normative power' (p. 119). To motivate the implausibility of this claim, Murphy invites the reader to consider the act of harming a harmless child, noting that theological voluntarism 'closes off the good of the child's life from being the, or even a, wrongmaking feature of the harming' (p. 118). This looks to be an appeal to our common-sense moral beliefs; specifically, to our belief that the fact that the child's life is good is at least part of what makes it wrong to harm the child. Murphy classifies this objection to theological voluntarism as an 'explanandum-centered' objection (p. 116) in that it alleges that theological voluntarism is unable to explain certain facts about morality (namely, that natural facts are not normatively inert).

I suggest that among our common-sense moral beliefs is the belief that some things distinct from God are intrinsically good: for example, the pleasure of an innocent backrub, or the love between parent and 
child. These things, it seems to me, are good in and of themselves. What makes them good, what explains their goodness, lies entirely within their intrinsic nature. If there are such intrinsic goods, then it appears that neither Murphy's nor Adams's theory can account for them, and this is a strike against both theories. This is an explanandum-centred challenge to Adams's and Murphy's accounts of the goodness of finite things.

Whatever the merits of this criticism, Murphy has written a book very much worth reading. By way of conclusion, I should emphasize that the book contains a number of stimulating arguments beyond those I have sketched here. In particular, Murphy offers some novel challenges for standard natural law theory and theological voluntarism that defenders of those approaches will want to consider - though whether Murphy's arguments will 'settle' the theological voluntarists as he suggests they should (p. 132) remains to be seen.

\section{JAMES D. MADDEN}

Benedictine College

\section{Charles Taliaferro, Jil Evans. The Image in Mind: Theism, Naturalism, and the Imagination. Continuum, 2011.}

The Image in Mind: Theism, Naturalism, and the Imagination is an attempt to bring a previously underemphasized consideration to the forefront of the theism-naturalism debate: the comparative aesthetic value of opposed worldviews. The authors, Charles Taliaferro and Jil Evans, endeavour to shift our attention away from the more directly evidential questions that currently dominate the theism vs. naturalism literature toward such questions as 'What is beautiful or ugly, deep or superficial, extravagant or empty, illuminating or stultifying about these images' (p. 1)? Whether naturalism can account for the emergence of specifically aesthetic values is a theme tracked throughout the book, but Taliaferro and Evans are equally interested in the prospects of naturalistic accounts of the emergence of ' ... life, sentience, consciousness, free will, and moral, aesthetic, and religious experience through non-purposive, impersonal forces' (p. 3). They offer substantial discussions of each of these issues, and in doing so they employ an aesthetic mode of evaluation. Despite its relative brevity, The Image in Mind competently treats this broad sweep 